\title{
The Anxiety Factors among Saudi EFL Learners: A Study from English Language Teachers' Perspective
}

\author{
Fariha Asif ${ }^{1}$ \\ ${ }^{1}$ English Language Institute, King Abdulaziz University, Jeddah, Saudi Arabia \\ Correspondence: Fariha Asif, English Language Institute, King Abdulaziz University, Jeddah, Saudi Arabia. Tel: \\ 966-55-013-0207. E-mail: farihaa83@yahoo.com
}

Received: March 1, 2017 Accepted: May 20, 2017 Online Published: May 26, 2017

doi: 10.5539/elt.v10n6p160 URL: http://doi.org/10.5539/elt.v10n6p160

\begin{abstract}
The purpose of this study is to investigate the factors that trigger language anxiety among Saudi learners in English as Foreign Language (EFL) classrooms. The factor of anxiety is especially found among learners while developing proficiency in over all communication and speaking skills as felt by the EFL teachers. The study also seeks to answer the questions like what are the socio-cultural factors as well as psycholinguistic factors that cause language anxiety. Furthermore, this study also explores strategies that can be designed and used to cope with language anxiety successfully. The scope of the study is limited to the college and university English teachers and subject specialists working in public sectors colleges and universities in Saudi Arabia.
\end{abstract}

Keywords: foreign language, communication, psycholinguistic factors, strategies, anxiety

\section{Introduction}

Encyclopedia of Psychology (2000) defines 'anxiety' as an emotion characterized by strong feelings of tension, worries and some physical changes including occasional increased blood pressure. In other words, it may be conceived as a phobea (feeling of fear), dismay, or restlessness, however, neither the sufferer nor the people around may not notice any apparent reasons for anxiety leading to emotional and physical changes. Language anxiety is one of the manifestations of general anxiety. Horwitz (2001) observes language anxiety as one of the most significant factors in booming language learning

\subsection{Concept of Anxiety}

The important and distinct role played by anxiety among various variables in foreign language (FL) learning is recognized by researchers Chastain (1975) and Scovel (1978). These researchers have shown foreign language anxiety found distinctive from construct of other anxieties (MacIntyre, 1993). "Anxiety is a psychological construct, commonly described by psychologists as a state of apprehension, a vague fear that is only indirectly associated with an object" (Hilgard, Atkinson and Atkinson, 1971: cited in Scovel, 1991, p.18). Horwitz (2001) asserted that poor linguistic performance of learner is the result of debilitative effect of language anxiety. Horwitz, Cope and Horwitz (1986) asserted that language anxiety is specific and unique. Among foreign language learners, speaking in class is found to be the most anxiety provoking element (Aida, 1994).

\subsection{Foreign Language Anxiety}

Horwitz, Cope and Horwitz (1986) conceived foreign language anxiety (FLA) as a situation specific anxiety, as foreign language anxiety which has a negative influence on language learning. They opined that even intelligent and apt individuals in native language face challenges while communicating in foreign language. MacIntyre and Gardner (1994) observed that students with any level of anxiety in foreign language face great difficulty in the demonstration of knowledge they possess.

\subsection{Xenoglossophobia: The Concept}

Xenoglossophobia, simply speaking is nothing but specific fear or anxiety of foreign languages. The word has been originated by three Greek words: xeno = foreign), glosso = language and phobia = fear. Xenoglossophobia is normally noticeable as a sign of extreme anxiety when exhibited with strange speech lacunae, in written or spoken course. 


\subsection{Causes of Foreign Language Anxiety}

Studies have revealed a negative relationship between language anxiety and achievement. To investigate factors of language anxiety in the Saudi EFL learners, is the central question of this research study. Young (1991: cited in Horwitz, Yan, 2008) pointed out that learners and teachers' beliefs, instructor-learner interaction, classroom procedures and language testing as factors associated with foreign language anxiety. Here, detailed investigation of anxiety provoking factors in Saudi EFL learners' academic context will possibly be explored. The study looks at the impacts of these factors on the language learning of the Saudi EFL learners as well as it enlists a few solutions to tackle the problem in the light of data collected from English teachers' interviews.

\subsection{Research Questions}

The study is carried out to explore the answers to the following questions:

1) What are the psycholinguistic reasons and factors that become the vital reason of language anxiety among ESL/EFL learners while learning and speaking English Language, especially in the context of the Saudi students?

2) What are the socio-cultural factors that cause language anxiety for the Saudi EFL learners in learning and speaking English Language?

3) What are the major signs of anxiety among Saudi EFL learners while learning the English language?

4) What strategies can be used to successfully cope with language anxiety?

\subsection{Purpose}

The purpose of this study is to find out language anxiety in Saudi EFL learners from the perspective of the EFL teachers who are extensively teaching in the Kingdom. Foreign language anxiety is one of the most challenging area of research as there are numerous questions associated with language anxiety that need to be explored and answered. Language anxiety appears to be the most important variable in language learning as many learners endure discomfort and frustration because of it. Research studies concerning learners' anxiety in relation to foreign language are inadequate in Saudi Arabia. Similar to the few previous studies in this area by many researchers, this study is a further step to investigate the factors which cause language anxiety in EFL learners from teachers' perspective in Saudi Arabia.

\section{Literature Review}

In this section, literature review is done in accordance with the research questions of the study. It is, therefore, considered that only those research studies are reviewed which are relevant and deal with the questions similar to those of this study. Here, some of them are reviewed. Second language acquisition (SLA) research has primarily started with a focus on concerns about language learning and teaching. Researchers posited that effective variables of learners should be taken into account to provide holistic understanding of the process of language anxiety (Samimy, 1994). Horwitz (2001) affirmed that the characteristics of affiliation between language learning anxiety and its subsequent achievement is disconcerted.

\subsection{Conceptual Foundations of Foreign Language Anxiety}

Foreign Language Acquisition (FLA) as a direct impact on the evaluation of individual's performance within educational and societal situation. The construct of Communication Apprehensions (CA) is highly related to the conceptualization of FLA due to its emphasis on interpersonal interactions ( Horwitz, Cope and Horwitz (1986). The concept of foreign language anxiety is being laid on the description of the above-mentioned components, giving an overview to figure out the causes or sources it can derive from. As speaking skills are being focused on, in this research, the first component (i.e. communication apprehension) will be elaborated extensively to provide an insight into the issue under study.

\subsection{Communication Apprehension (CA)}

Horwitz et al. (1986, p. 128) elaborated and explained communication apprehension as "a type of shyness characterized by fear or anxiety about communicating with people". In foreign language anxiety CA plays a vital role in success or failure of learners. In addition to feelings less in control of the communicative situation, they also may feel that their attempts at oral work are constantly being monitored(Horwitz, et al., 1986). This nervousness is elaborated with the inability of learners to understand others and make others understand it; results in negative self-perceptions of learner's (MacIntyre \& Gardner, 1989).

\subsection{Test Anxiety}

In most of the foreign language classes, performance evaluation is a regular feature: this evaluative performance 
leads to test anxiety. Therefore, an insight into test anxiety is also significant in understanding the construct of foreign language anxiety. Horwitz et al. (1986, p. 127), explained test anxiety as, "a type of performance anxiety stemming from a fear of failure". Test-anxious students may impose unrealistic beliefs regarding language learning.

\subsubsection{Fear of Negative Evaluation}

Horwitz et al (1986, p. 128) defined fear of negative evaluation as "apprehension about others' evaluations, avoidance of evaluative situations, and the expectation that others would evaluate oneself negatively" which is a third category of anxiety associated with foreign language learning.

\subsection{Anxiety at Three Stages of Language Learning}

In order to communicate in foreign language, acquisition of FL is required (Baker \& MacIntyre, 2003). However, the learning of a foreign language involves many complexities and difficulties for language learners; and can become the cause of language anxiety among EFL learners. Linguistically saying "students' anxiety about FL learning is likely to be a consequence of their language learning difficulties" (Sparks, Ganschow, \& Javorsky, 2000).

\subsubsection{Input Stage}

Krashen(1985, p. 3) defined 'Input Hypothesis' in these words, "speech cannot be taught directly but emerges on its own as a result of building competence via comprehensible input". At the input stage 'affective filter' reduces the efficacy of input by limiting the ability of anxiety bearing students to be fully attentive to instructor's material and limiting the students' ability to represent internal input (Tobias, 1977).

\subsubsection{Processing Stage}

The extent of processing anxiety experienced depends on intricacy of the information, reliance on memory and organization of the material presented (Tobias, 1986). During communication "complex and non-spontaneous mental operations are required" to carry out these operations and malfunctioning to perform so could "lead to reticence, self-consciousness, fear or even panic" (Horwitz, et al., 1986, p. 128). MacIntyre (1995) draws a triangle among three variables anxiety, behaviour and cognition and affirms that all these three are interlinked.

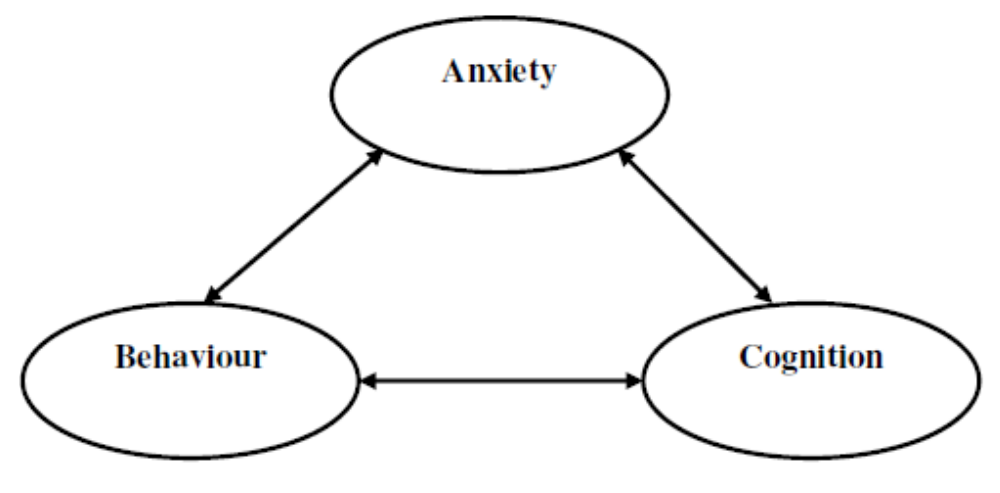

Figure: 2 Recursive relations among anxiety, cognition and behaviour

Figure 2. Reveals that anxiety, behaviour and cognition are interconnected

The learner's ability to comprehend messages or to learn new vocabulary items is hindered by high levels of processing anxiety.

\subsubsection{Output Stage}

Anxiety mostly appears at output stage when communicating in learner's target language. This occurs after the successful end of the previous two stages: processing and input. While, anxiety, on the other hand, at output stage involves the apprehension and fright experienced by learners when asked for demonstration of previously learned knowledge (Bailey et al., 2000). Tobias (1977) opined the occurrence of interference at this stage, which 
arises after the successful completion of processing and before effective production of output.

\subsection{Socio-Cultural Factorsand Anxiety}

The previous part has revealed that problems encountered by learner in the acquisition of foreign language at the output stage within the classroom environment elucidate the potential causes of Language Acquisition (LA). Moreover, social and communicative features of language learning are also a source of language anxiety.

\subsubsection{Social Environment for FL Acquisition}

Foreign language learning can be acquired in two divergent types of social backgrounds 1) community which do not use target language as L1 2) community which use target language as L1. In the former type of background, foreign language learners are exposed to narrow and defective input. For such learners Krashen (1985, p. 46) stated, "The only input is teachers' or classmates' talk- both do not speak L2 well". Such learners cover only a smaller discourse type, as in such kind of environments, limited exposure to target language is provided as classroom is the only source of language input and practice. Sociolinguists postulate that conversational interaction is influenced by social relationships. Wolfson (1989, p. 131), in her theory of 'Social Interaction', posited that inequality of social distance and status "disfavour attempts at negotiation".

\subsubsection{Intercultural/Interethnic Communication Apprehension (ICA)}

Intercultural and interethnic interaction also triggers communication anxiety. When people interact with individuals of other cultures and face cultural differences, they incline to view people as strangers. "The fear or anxiety associated with either real or anticipated interaction with people of different groups, especially cultural and ethnic and/or racial groups" (Neuliep \& McCroskey, 1997, p. 145).

\subsubsection{Techniques to Cope with Language Anxiety}

Research on language anxiety recommends a variety of techniques and activities tailored to successfully reduce and deal with the problem of language anxiety. Foss and Foss and Reitzel (1988) offer various techniques to reduce language anxiety emerging from a learner's beliefs. The same techniques will be applied while treating personal and interpersonal anxieties.

\subsection{An Overview}

The study conducted by Yahya M. (2013) is of special significance in terms of its context being carried out in the Arab culture background. He investigated the factors which lead to speaking anxiety among the Arab EFL learners in English language classroom. The findings of his study revealed that the fear of negative feedback received the highest mean (2.93), followed by communication anxiety (2.80) and test anxiety received the lowest mean (2.68). Some studies assured the role of the teacher, classmates, techniques, time, content, fear of getting bad grades, worry, types of activities and lack of preparation may increase students' anxiety in the language class Studies clearly show that speaking English before the class or delivering their presentations, reported to be a major cause of anxiety as students fear of making mistakes before their peers. No studies were conducted in the Arab World in general and Saudi Arabia in particular. This emphasizes the vital need for conducting such studies. Unfortunately, not much work has been done in terms of Saudi EFL learners' context and, therefore, it is required to conduct studies related to various areas of English language learning focusing the Saudi EFL learners. It is required that the situation of the Saudi EFL learners be explored in a distinct study. This present study seeks to take EFL teachers' point of view on the factors that cause anxiety among the Saudi EFL learners.

\section{Methods of the Study}

The study is carried out to explore the answers to research questions. In order to find the answers, qualitative as well as quantitative research methods were used. To this end, the researcher opted to apply two research tools, one each for each type of research methods.

\subsection{Qualitative and Quantitative Study}

To find answers to the research questions relating to, the perceptions of teachers on this phenomenon of language anxiety were investigated in the Saudi context by the EFL teachers of university at graduate level by using qualitative research strategy. This method allows the researcher to gain insight into the subjective world of human experiences by revealing the inner thoughts of a person and to provide an understanding from within (Cohen, Manion \& Morison, 2007) Mixed mithods methodology is adapted in the form of Questionnaire different types of interviews in qualitative-descritive research.

\subsection{Rationale for Selecting Mixed Method Strategy}

In order to get a deeper insight into the process of language anxiety, its construct and various other factors 
associated with it, different approach of research is required from that of a quantitative study. Thus, the present research used qualitative method of research, as this approach of research allows researcher to collect descriptive information on various variables, not assessed easily through empirical research and also lends to view the phenomenon from perspective of the subjects. (Price, 1991).

\subsubsection{Questionnaire for Teachers}

First, to collect quantitative data, a questionnaire with twenty (20) items was used to seek the opinion of the EFL teachers about the anxiety factors in the Saudi EFL learners.

\subsubsection{Structured Interviews}

Secondly, the structured interview technique was used by the researchers to get detailed opinion from the EFL teachers about the factors of anxiety among the Saudi EFL learners. The rationale behind the use of interviews as a data collection technique was that it can provide access to things that could not be directly observed, such as feelings, intentions, thoughts, or beliefs (Denzin, 1988; Merriam, 1998). As the focus of this research is to explore various sources of language anxiety, various manifestations associated with it and the strategies to cope with the problem successfully, interviews seemed to be an appropriate tool as they also allow for clarification and elaboration of points when required.

\subsection{Research Design}

The research design comprises two tools; a questionnaire from one hundred $(n=100)$ EFL teachers and interviews with fifteen $(n=15)$ other EFL teachers, working in various colleges and universities in different cities of Saudi Arabia. The interpretive method of research was used for this study.

\subsubsection{Participants}

To study the factors that cause English language learning anxiety among the Saudi EFL learners, a total of one hundred and fifteen $(n=115)$ respondents who have been teaching English in various colleges and universities in Saudi Arabia were randomly selected to conduct the research questionnaire and interviews.

\subsubsection{Profile and Interviews of the Research Participants}

Professional profiles of the respondents are of immense significance in an educational research because they provide valuable insight by giving the responses about the problem. Keeping this in mind, all the fifteen respondents of interviews were requested to provide their professional profiles and they are presented in the appendices section.

\subsubsection{Research Instruments}

Two research instruments were used for this research. They are detailed here;

\section{A. Five Point Scale Questionnaire}

For the quantitative data, a Likert scale (5-point scale questionnaire) with twenty (20) items was used to seek the opinion of the EFL teachers about the factors of anxiety among the Saudi EFL learners. In the Likert scale, 'strongly disagree' is usually coded as 1 , 'disagree' as 2 , neutral as 3 , 'agree' as 4 and 'strongly agree' as 5 . The same principle was used in this research. Before using the questionnaire, its validity and the reliability were tested. The reliability and internal consistency of the questionnaire was checked applying the Cronbach's Alpha coefficient reliability test on it. To apply the test, the questionnaire was initially given to 20 teachers teaching in some Saudi universities. The responses of the teachers were put in the excel sheet and the Cronbach's Alpha coefficient was calcualted. The internal consistency coefficient result was 0.87 which indicated a high internal consistency and reliability.

\begin{tabular}{|l|l|}
\hline Cronbach Alpha Test \\
\hline Cronbach's Alpha & No. of Items \\
\hline $\mathbf{0 . 8 7}$ & $\mathbf{2 0}$ \\
\hline
\end{tabular}




\section{B. Structured Interviews}

For qualitative data, structured interviews with the 15 professional teachers working at Saudi colleges/universities were conducted to seek their opinion on the anxiety factors the Saudi EFL learners face in English language learning (Appendix B).

\section{Analysis of the Data}

\subsection{Analysis of Interview Data}

Qualitative data was collected from the structured interviews with 15 EFL teachers working at Saudi colleges and universities. The interviews were audio recorded, transcribed and then analysed.

Table. 1 Summary of the responses on interview questions

\begin{tabular}{ll}
\hline Questions & Responses from different interviewees \\
\hline Q.1 & $\begin{array}{l}\text { Exam, Cramming, Apprehension, Nervousness, failing to achieve desired goals, anxiety has bad } \\
\text { effects, lack of participation, making mistakes, making mistakes, composure and fluency, learning } \\
\text { process and proficiency, Fear of being scorned, problems in communication, will be making fun } \\
\text { of, incompetence in foreign language, making mistakes and fear of being judged, self-conscious } \\
\text { and more inhibitive, short cut way } \\
\text { L1 interruption. Interlocutor problems, reproduce of a foreign tongue, very few opportunities, lack } \\
\text { of vocabulary, Fear of losing self-respect, inferiority complex, fear of committing mistakes, } \\
\text { Students become nervous, diversion of attention, stammering in oral expression, formal } \\
\text { atmosphere, low self esteem, lack of interest and flare } \\
\text { false starts, pauses, hesitations, Deliberate timidity, Fear of being ridiculed. broken sentences } \\
\text { talkativeness with other students, negative outcomes, group work or interact, Avoidance and, } \\
\text { procrastination, Encouraging of students, Productive skills, restlessness, low energy level } \\
\text { negative feedback, quavering voice, previous negative experiences, feeling choked, strangeness } \\
\text { Classroom Speaking, accumulate a lot of tasks, role playing activities, Unjust assessment } \\
\text { Reading aloud, Public speaking, speaking activities, discussion in open-class-forum, Constant } \\
\text { motivational strategies, Random talk, lowly involvement in classroom, motivation and persuasion, } \\
\text { not giving a chance to the students to warm up, hands become cold and sweaty, Lot of homework, } \\
\text { burdensome assignments } \\
\text { positive constructive feedback, Audio and video recording students, keep them engaged, practice } \\
\text { opportunities, working in pairs, identifying perfectionist tendencies, atmosphere of } \\
\text { competitiveness, use of drama-like and role-play activities, encouragement, use ice-breakers, } \\
\text { presentation in front of the class, Taking in confidence, Tolerant and accommodating teaching, } \\
\text { Develop a rapport with students, base should be made strong in learning English }\end{array}$ \\
\hline
\end{tabular}

\subsubsection{Effects of Anxiety on Learners' Performance}

A respondent of the study is of the view that anxiety hampers learners' proficiency. She said, "Proficiency is impeded by anxiety and especially by the common practice of memorizing ready-made answers. In fact, anxiety itself seems to motivate students to memorize texts and sample answers instead of trying to answer on their own". (Interview1)

Tanveer, M. (2007, p. 1) writes, “In many cases, students'feeling of stress, anxiety or nervousness may impede their language learn and performance abilities. Theorists and second language acquisition (SLA) researchers have frequently demonstrated that these feelings of anxiety are specifically associated with learning and speaking a second/foreign language, which distinguishes L2/FL learning from learning other skills or subjects".

The above quotes, both from the respondents of this study and the other empirical works, go on to establish significant role of anxiety, positive or negative. However, it is clear that the effects of anxiety in language learning cannot be under-estimated.

\subsubsection{Factors that Cause Anxiety for the Saudi EFL Learners}

Both the opinions of the teachers expressed in their interviews conducted by the researcher and the ideas 
expressed in the existing studies seem to converge on the anxiety causing factors.

\subsubsection{L1 Interference}

Among others, one major factor counted by the professional teachers is the interference of Arabic language that causes foreign language learning anxiety for the Saudi EFL learners. A respondent of this study states it in these words: "There are few opportunities for the Saudi learners to practice English and students do not always take advantage of all the possibilities offered to them. In classrooms, corridors and within the English language centers itself, students keep speaking Arabic as soon as they have a chance”. (Interview 1).

Another respondent finds the root cause in the Saudi society and their community as a whole. She puts it this way;

"Demographically, Saudi Arabia is a homogeneous community with one common language running through the length and breadth of the country. Students find it difficult to learn English firstly because; they have not needed to learn it". (Interview 3).

\subsubsection{Fear of Making Mistakes}

Another factor highlighted by many of the respondents is fear of making mistakes. A respondent of this study states it in these words; "Fear of failure or making mistakes, even though they are a bit prepared, causes anxiety" (Interview 7).

Respondent 8 gives a detailed description of what she thinks the anxiety causing factor is. She says; "In my view, there are a number of factors that cause anxiety among Saudi EFL learners specially in speaking skill. They include peer humiliation, talking in front of native speakers, pronunciation concerns, and classroom environment" (Interview 8).

\subsubsection{Performance Anxiety}

Most of the respondents seem to converge that the fear of bad performance is one of the major anxiety causing factors among the Saudi EFL learners. One of the respondents says; "Students seem afraid of being judged by their peers. So any speaking in front of the whole class may aggravate anxiety". (Interview 1).

This factor finds its roots in other international studies as well. For instance, Young (2004) conducted an interview study on eight Korean EFL university students and chalked down a list of nine (9) factors that cause English language learning anxiety among the Korean EFL learners. One of them was "speaking English in front of the class" (Young, 2004, p. 17).

4.1.3 Major Signs of Anxiety among Anxious Learners

There are so many signs from which anxiety among Saudi EFL learners can be traced out.

\subsubsection{Physical Gestures and Non-Verbal Signs}

According to EFL teachers' interviews, some of these signs are analysed as following. Hesitation, verbal staggering, feeling choked, waywardness, confusion and inconsistent speech are the major signs of anxiety. Participant 13 expressed the gist of his experience in these words, "During my 24 years' experience, I have noticed many signs of xenoglossophobia. First of all is stammering in oral expression, there is dumbness or incoherence in verbal expression." (Participant 13).

\subsubsection{Non-Participatory Role in EFL Class}

Non-participation in classroom activities is another sign of anxiety. As participant \#12 told in her interview, "The most prominent of these are quavering voice while trying to speak. Some learners express anxiety through shaky hands/sweaty palms and some remain reluctant to participate in class discussions, speaking activities. They also try to hide behind other students." (Participant 13).

\subsubsection{Type of Activities, Skills and Classroom Situations that Aggravate Anxiety}

This question was related to indicate the enhancing factor of EFL anxiety. Sometimes some EFL teachers unknowingly become a cause of anxiety boosters and some of them become a cause of it due to their unawareness.

\subsubsection{Classroom Strict/Dictatorial Environment}

Some of the teachers in their interview expressed this view that EFL teachers must give some space to their students. Humera, participant .11 affirmed in these words, "Some other activities are submitting and reading answers in front of class if reading is poor. This can enhance anxiety level. Too much noise in the class and sometimes lack of IT skills can also worsen the situation. A strict environment in the class may become another 
cause of anxiety enhancement" (Interview 11).

This shows that sometimes infrastructural issue may be a cause of increasing anxiety among EFL learners.

\subsubsection{Negative Feedback of the Teacher}

Teachers are considered to be kind and compassionate guides who always try to teach and instruct learners with politeness. According to participant No 12, "Negative feedback of the teacher is the greatest reason of enhancing anxiety among EFL learners. In Saudi Arabia, most of the EFL teachers have been hired from abroad, some of them get irritated on low performance of learners. They demoralize them in one way or the other. They expect from them beyond ground realities" (Interview 12).

\subsection{Analysis of Questionnaires}

Questionnaire data was collected through a questionnaire filled by 100 EFL lecturers teaching English as a foreign language at various Saudi Arabian universities. For each measure, the mean, standard deviation, median, mode, and score range were calculated to determine what the EFL teachers felt about the anxiety factors of the Saudi EFL learners. Then, analysis was done to describe the findings about the teachers' beliefs on the Saudi EFL learners' foreign language anxiety, motivation, and their predictive effect on the students' performance in English.

4.2.1 Questionnaire Data: Tabular Presentation

\begin{tabular}{|c|c|c|c|c|c|c|}
\hline Questionnaire items & $\mathrm{N}$ & Minimum & Maximum & Sum & Mean & Std. Deviation \\
\hline 1 & 100 & 1 & 5 & 312 & 3.12 & 1.358 \\
\hline 2 & 100 & 1 & 5 & 334 & 3.34 & 1.249 \\
\hline 3 & 100 & 1 & 5 & 348 & 3.48 & 1.227 \\
\hline 4 & 100 & 1 & 5 & 351 & 3.51 & 1.251 \\
\hline 5 & 100 & 1 & 5 & 401 & 4.01 & .927 \\
\hline 6 & 100 & 1 & 5 & 349 & 3.49 & 1.235 \\
\hline 7 & 100 & 1 & 5 & 365 & 3.65 & 1.104 \\
\hline 8 & 100 & 1 & 5 & 425 & 4.25 & 1.019 \\
\hline 9 & 100 & 1 & 5 & 351 & 3.51 & 1.202 \\
\hline 10 & 100 & 1 & 5 & 389 & 3.89 & 1.072 \\
\hline 11 & 100 & 1 & 5 & 338 & 3.38 & 1.213 \\
\hline 12 & 100 & 1 & 5 & 351 & 3.51 & 1.299 \\
\hline 13 & 100 & 1 & 5 & 371 & 3.71 & 1.149 \\
\hline 14 & 100 & 1 & 5 & 375 & 3.75 & 1.067 \\
\hline 15 & 100 & 1 & 5 & 341 & 3.41 & 1.264 \\
\hline 16 & 100 & 1 & 5 & 353 & 3.53 & 1.291 \\
\hline 17 & 100 & 1 & 5 & 334 & 3.34 & 1.249 \\
\hline 18 & 100 & 1 & 5 & 415 & 4.15 & .989 \\
\hline 19 & 100 & 1 & 5 & 343 & 3.43 & 1.233 \\
\hline 20 & 100 & 1 & 5 & 334 & 3.34 & 1.249 \\
\hline 21 & 100 & & & & & \\
\hline
\end{tabular}




\subsection{Summary}

The data analysis brings enough evudence to answer research questions of this study. The following important points can be presented as sum and substance of this study:

- The Saudi EFL learners suffer from anxiety especially in speaking skills.

- Anxiety affects the Saudi EFL learners' proficiency in English language learning.

- Some of the anxiety causing factors are psycholinguistic and are related to foreign language learning processes while others are socio-cultural and find their roots in Saudi culture and society.

- Anxiety manifests in many different ways in the conduct of the Saudi EFL learners from poor performance in English language learning to making frequent mistakes and nervousness on the part of the learners while presenting in front of others.

- EFL Teachers and language instructors have vital role to play in minimizing the negative effects of anxiety in English learning classes.

\section{Findings, Conclusions and Recommendations}

The study has been a great source of learning and experience for the researcher. All of its processes from questionnaire development to testing its reliability and validity and planning and conducting structured interviews transcribing them were very exciting and interesting for the researcher. After data collection, started the stage of analyzing it. This was the core part of the study.

\subsection{Findings}

The main findings of this research study in the light of English teachers' responses can be summed up here as;

1) Anxiety plays an important role in English as foreign language learning for the Saudi EFL learners.

2) The respondents of the study seem to have a consensus that first language (L1) interference is one of the major factors that cause anxiety among the Saudi EFL learners.

3) Most of the Saudi EFL learners are found to have a level offear of making mistakes.

4) Discouraging classroom environment is also counted as one of the major anxiety causing factors.

5) Some Saudi EFL learners have also been reported to suffer from performance anxiety.

6) Lack of English vocabulary is another significant factor that causes anxiety among the Saudi EFL learners.

7) English language teachers have their important role to minimize the negative effects of anxiety in their classes. The teachers' positive encouragement can do wonders in this regard.

8) A positive, motivating and encouraging class environment is essential to produce desired results in English language learning for the Saudi EFL learners.

9) Learners need to be taught how to manage their time effectively in and outside the classroom.

10) Pair and group work activities can help a lot in reducing the adverse effects caused by anxiety.

In addition to psycho-linguistic factors, many socio-cultural factors have strong influence on learners which stimulate speaking anxiety in them. Most commonly conversed socio-cultural (the factors related to particular society and culture) factors in this study were social status, difference of schooling system, gender and cultural differences etc. This section discusses the identified socio-cultural factors in detail that exerts pressure on learners and produces anxiety in EFL learners in Saudi socio-cultural context. The cultural difference between learners and target language is one of the anxiety-provoking factors. This factor was identified by very few respondents in this current study. While in earlier studies, this was found to be one of the most important factors. Teachers tried to assure students that making mistakes is a part of learning and motivate them to speak and practice. Teachers should be encouraging and they should not be pointing out mistakes in front of the whole class as it can de-motivate the speakers. Many teachers posited that the behaviour of teachers should not be harsh towards students when they make mistakes. They also uttered that students should be encouraged to participate in classroom activities. The role of teacher was highlighted by majority of participants. They believed that teachers have a great role to play in classrooms in creating or reducing anxiety. A suggestion was given that teacher should be tolerant enough to make comfortable environment of language classroom. Teachers should also be a real support and a source of guiduance for their students. Many teachers expressed their own opinion that they should consider the problems of the learners and counsel students for better learning and speaking. Contrary to the work of Young (1991) some of the teachers believed on assigning pair and group work which 
lessens the burden and builds confidence in speakers as they feel support of their fellows. An effective suggestion was given by a teacher to learners that in order to overcome their fear of foreign language that they should attend some stress management workshops. These will also be helpful in treating self-created perceptions of students about language.

\subsection{Conclusion}

English speaking proficiency is a complex skill and it needs continuous practice as per English teachers' stance reflected through the data, collected through interviews and questionnaire. The learners should be able to practice their language skills without the threat of evaluation. It was found that by focusing on the process of speaking students acquired a useful tool to raise their English spoken ability. The results of the study indicate that speaking is foundational in learning a foreign language. As recommended by the participant English teachers, language anxiety, it can be postulated, may not require any 'special treatment' but what it does demand, is the careful attitude of the language teachers in order to understand and to effectively diagnose this phenomenon among the learners. Thus, it requires the application of modern approaches that lay emphasis on enhancing learning opportunities in an environment that is conducive to learning.

\subsection{Recommendation}

- Only relaxed and composed teachers can reduce the students' anxiety. If a teacher is over anxious or frustrated, the learners will definitely take some effect from the teacher's behavior.

- As noted, most of the Saudi EFL learners suffer from anxiety because they are afraid of making mistakes. Teachers should encourage the learners not to be afraid of making mistakes.

- Language teachers should create a positive class atmosphere in their EFL classroom settings. Such congenial classroom environment can ensure better learning opportunities for the Saudi EFL.

- Most of the times, teachers need to be experimenters and researchers in order to find out the challenges their students face and try out different ways to solve those issues.

- Positive and effective use of teaching tactics such as humor, friendly relationship, supportive environment, and use of technology, attractive material and positive way of correcting mistakes can help a lot in minimizing the anxiety among the Saudi EFL learners.

- Three approaches (cognitive, affective, and behavioral) presented by Hembree (1988: cited in Ying-Ling \& Kondo, 2004) are recommended for selecting right strategy to handle the anxious learners.

- Professional development courses for the teachers to train them and make them aware of the complex issue related to learners' anxiety and to prepare them for good strategies to reduce anxiety could be very useful.

\subsection{Suggestion for Future Research}

The previous as well as current research shows the existence of different levels of language anxiety in learners specific to language classroom. Due attention on the following identified areas is required by future researchers in the same field.

1) In order to provide the comprehensive picture of complex phenomenon of language anxiety in Saudi EFL learners, the research on all the four skills is required. This will help teachers to eradicate this problem to maximum level in learners in language classrooms.

2) The further investigation can be done to check the relationship of different variables already identified in this research.

3) With the help of this study, comparative research can be done among students of Saudi Arabia and students of other cultures. This will reveal the significant differences between factors and their manifestations due to cultural changes.

4) The comparative research on learners belonging to each social class; or for rural and urban areas of the Kingdom can be conducted. This will affirm the significant difference of learners to each social strata of Saudi society. 


\section{References}

Adams, M. J. (1998). Beginning to read: thinking and learning about print. Cambridge, MA: MIT Press.

Aida, Y. (1994). Examination of Horwitz, Horwitz, and Cope's construct of foreign language anxiety: The case of students of Japanese. Modern language journal, 78(2), 155-168. https://doi.org/10.2307/329005

Allington, R. L. (1983). Fluency: the neglected reading goal in reading instruction. The reading teacher (Newark, $D E), 36,556-61$.

Andrade, M., \& Williams, K. (2009). Foreign Language Learning Anxiety in Japanese EFL University Classes: Physical, Emotional, Expressive, and Verbal Reactions. Sophia Junior College Faculty Journal, 29, 1-24.

Argyle, M. (1994). The psychology of social class: Psychology Press.

Arnold, J. (2000). Speak easy: How to ease students into oral production. Pilgrims Ltd.

Backman, N. (1976). Two measures of affective factors as they relate to progress in adult second-language learning. Working Papers on Bilingualism, 10, 100-122.

Bailey, K. M. (1983). Competitiveness and anxiety in adult second language learning: Looking at and through the diary studies. In H. W. Seliger, \& M. H. Long (Eds.), Classroom oriented research in second language acquisition. Rowley, MA: Newbury House.

Baker, S. C., \& MacIntyre, P. D. (2003). The role of gender and immersion in communication and second language orientations. Language learning, 53(S1), 65-96. https://doi.org/10.1111/0023-8333.00224

Baki, R. (2012). Exploring Language Anxiety Regarding Speaking Skill in Iranian EFL Learners in an Academic Site in Malaysia. International Journal of Applied Linguistics \& English Literature, 1, 153-154. https://doi.org/10.7575/ijalel.v.1n.2p.153

Brandl, K. K. (1987). Eclecticism and Teaching Communicative Competence. Unpublished master's thesis, University of Texas at Austin.

Burns, N., \& Grove, S. K. (1997). The Practice of Nursing Research Conduct, Critique, \& Utilization. Philadelphia: W.B. Saunders and Co.

Campbell, C. M., \& Ortiz, J. (1991). Helping students overcome foreign language anxiety: A foreign language anxiety workshop. Language anxiety: From theory and research to classroom implications, 153-168.

Carrier, K. (1999). The social environment of second language listening: Does status play a role in comprehension? The Modern Language Journal, 83(1), 65-79. https://doi.org/10.1111/0026-7902.00006

Chastain, K. (1975). Affective and ability factors in second language acquisition. Language Learning, 25(1), 153-161. https://doi.org/10.1111/j.1467-1770.1975.tb00115.x

Chen, Y. (2005). Barriers to acquiring listening strategies for EFL learners and their pedagogical implications. TESL-EJ, 8(4), 1-25.

Clay, M. M. (1985). The early detection of reading difficulties (3rd ed). Portsmouth, NH: Heinemann.

Cohen, A. D., Oxford, R. L., \& Chi, J. C. (2001). Language Strategy Survey. Minneapolis, MN:Center for Advanced Research on Language Acquisition, University of Minnesota.

Cohen, L., Manion, L., \& Morrison, K. R. B. (2000). Research methods in education (5th ed.). London Routledge Falmer. https://doi.org/10.4324/9780203224342

Daly, J. (1991). Understanding communication apprehension: An introduction for language educators. Language anxiety: From theory and research to classroom implications, 3-13.

Denzin, N. (1988). The research act (Rev. ed.): New York: McGraw-Hill, p. 110.

Dewaele, J. M. (2002). Psychological and socio-demographic correlates of communicative anxiety in L2 and L3 $\begin{array}{llllll}\text { production. } & \text { International }\end{array}$ https://doi.org/10.1177/13670069020060010201

Cohen, L., Manion, L., \& Morison, K. (2007). Research Methods in Education (6th ed.). London: Routledge.

Foss, K. A., \& Reitzel, A. C. (1988). A relational model for managing second language anxiety. Tesol Quarterly, 22(3), 437-454. https://doi.org/10.2307/3587288

Horwitz EK, Horwitz MB, Cope J. (1986). Foreign language classroom anxiety. Modern Lang. J, 70(2), $125-132$. https://doi.org/10.1111/j.1540-4781.1986.tb05256.x 
Horwitz, E. K. (1991). Preliminary evidence for the reliability and validity of a foreign language anxiety scale. In E. K. Horwitz, \& D. J. Young (Eds.), Language anxiety: From theory and research to classroom implications (pp. 37-39). Englewood Cliffs, New Jersey: Prentice Hall.

Horwitz, E. K. (2000). Horwitz comments: It ain't over 'til it's over: On foreign language anxiety, first language deficits, and the confounding of variables. The Modern Language Journal, 84(2), 256-259. https://doi.org/10.1111/0026-7902.00067

Horwitz, E. K. (2001). Language anxiety and achievement. Annual Review of Applied Linguistics, 21, 112-126. https://doi.org/10.1017/s0267190501000071

MacIntyre, P. D. (1995). How does anxiety affect second language learning? A reply to Sparks and Ganschow. The Modern Language Journal, 79(1), 90-99. https://doi.org/10.1111/j.1540-4781.1995.tb05418.x

Krashen, S. D. (1985). The input hypothesis: Issues and implications: Longman. p. 3.

Neuliep, J. W., \& McCroskey, M. C. (1997). The development of intercultural and interethnic communication apprehension scales. Communication Research Reports, 14(2), 145-156. https://doi.org/10.1080/08824099709388656

Price, M. L. (1991). The subjective experience of foreign language anxiety: Interviews with highly anxious students. Language Anxiety. From Theory and Research to Classroom Implications. Upper Saddle River, NJ. Prentice Hall, 101-108.

Scovel, T. (1978). The effect of affect on foreign language learning: A review of the anxiety research. Language Learning, 28(1), 129-142. https://doi.org/10.1111/j.1467-1770.1978.tb00309.x

Sparks, R. L., \& Ganschow, L. (2007). Is the foreign language classroom anxiety scale measuring anxiety or $\begin{array}{llll}\text { language skills? Foreign } & \text { Language }\end{array}$ https://doi.org/10.1111/j.1944-9720.2007.tb03201.x

Tobias, S. (1977). A model for research on the effect of anxiety on instruction. Anxiety, learning, and instruction, 223-240.

Tobias, S. (1986). Anxiety and cognitive processing of instruction. Self-related cognitions in anxiety and motivation, 35-53.

Wolfson, N., \& Languages, T. O. E. T. S. O. O. (1989). Perspectives: sociolinguistics and TESOL: Newbury House.

Yahya, M. (2013). Measuring speaking anxiety among speech communication course students at the Arab American University of Jenin (AAUJ). European Social Sciences Research Journal, 1(3), 229-248

Young, D. J. (1991). Creating a low-anxiety classroom environment: What does language anxiety research suggest? Modern language journal, 75(4), 426-439. https://doi.org/10.1111/j.1540-4781.1991.tb05378.x

Young, D. J. (2004). The teacher as facilitator: reducing anxiety in the EFL university classroom. Classroom Implications. Englewood Cliffs, NJ: Prentice Hall, pp.15-24.

\section{APPENDIX -A}

\section{Questionnaire}

The purpose of the study is to find what causes language anxiety among the Saudi EFL learners in learning speaking skills. The study also aims at exploring the influence anxiety casts on communication in the English language learning. This questionnaire is designed for academic research. It contains 20 items that may reflect your feelings about your English class. After reading each statement, please circle the number and indicate whether you

(1) strongly disagree (2) disagree (3) Neutral (4) agree 5) Strongly disagree

Your answers are considered to be highly valuable and will also be kept confidential. Note that there is no right or wrong response to any of the items on this survey.

\section{Part A: Background information}

1. What is your sex?
a) Male
b) Female 
2. How many years have you been teaching English in Saudi Arabia?
a) 1 to 3 years
b) 4 to 6 Years
c) 7 to 10 years
d) More than 10 years

3 . Where are you teaching at present?
a) university
b) college
c) high school
d) primary school

\section{Part B: Survey of the anxiety and its factors}

\begin{tabular}{|c|c|c|c|c|c|c|}
\hline $\mathbf{S}$ & Statements & $\begin{array}{l}1 \\
\text { Strongly } \\
\text { disagree }\end{array}$ & $\begin{array}{l}2 \\
\text { Disagree }\end{array}$ & $\begin{array}{l}3 \\
\text { Neutral }\end{array}$ & $\begin{array}{l}4 \\
\text { Agree }\end{array}$ & $\begin{array}{l}5 \\
\text { Strongly } \\
\text { agree }\end{array}$ \\
\hline 1 & $\begin{array}{l}\text { Most of the Saudi EFL learners feel frightened } \\
\text { when they don't understand what I say in class. }\end{array}$ & & & & & \\
\hline 2 & $\begin{array}{l}\text { Most of the Saudi EFL learners get nervous when } \\
\text { they don't understand the words their English } \\
\text { teachers say. }\end{array}$ & & & & & \\
\hline 3 & $\begin{array}{l}\text { Most of the Saudi EFL learners worry that their } \\
\text { English listening ability is not good. }\end{array}$ & & & & & \\
\hline 4 & $\begin{array}{l}\text { Most of the Saudi EFL learners don't dare to } \\
\text { speak English with foreigners. }\end{array}$ & & & & & \\
\hline 5 & $\begin{array}{l}\text { Most of the Saudi EFL learners make many } \\
\text { mistakes when I ask them to answer questions in } \\
\text { English. }\end{array}$ & & & & & \\
\hline 6 & $\begin{array}{l}\text { Most of the Saudi EFL learners worry that they } \\
\text { are unable to communicate with others owing to } \\
\text { their low English proficiency. }\end{array}$ & & & & & \\
\hline 7 & $\begin{array}{l}\text { Most of the Saudi EFL learners get nervous when } \\
\text { they have listen and respond to someone in } \\
\text { English. }\end{array}$ & & & & & \\
\hline 8 & $\begin{array}{l}\text { Most of the Saudi EFL learners are afraid of } \\
\text { making mistakes in front of their classmates when } \\
\text { they are taking an oral test. }\end{array}$ & & & & & \\
\hline 9 & $\begin{array}{l}\text { Most of the Saudi EFL learners get nervous when } \\
\text { a teacher asks them questions in English class. }\end{array}$ & & & & & \\
\hline 10 & $\begin{array}{l}\text { Most of the Saudi EFL learners get anxious when } \\
\text { there are many words they don't know on English } \\
\text { tests. }\end{array}$ & & & & & \\
\hline 11 & $\begin{array}{l}\text { Most of the Saudi EFL learners respond slowly in } \\
\text { their English speaking tests. }\end{array}$ & & & & & \\
\hline 12 & $\begin{array}{l}\text { Most of the Saudi EFL learners are afraid that the } \\
\text { other learners will laugh at them if they do an } \\
\text { English presentation. }\end{array}$ & & & & & \\
\hline 13 & $\begin{array}{l}\text { Most of the Saudi EFL learners are afraid of } \\
\text { making many grammatical mistakes in speaking } \\
\text { English language. }\end{array}$ & & & & & \\
\hline 14 & $\begin{array}{l}\text { Most of the Saudi EFL learners have a very } \\
\text { limited vocabulary. }\end{array}$ & & & & & \\
\hline 15 & $\begin{array}{l}\text { Most of the Saudi EFL learners feel nervous while } \\
\text { listening to native English speakers or their }\end{array}$ & & & & & \\
\hline
\end{tabular}




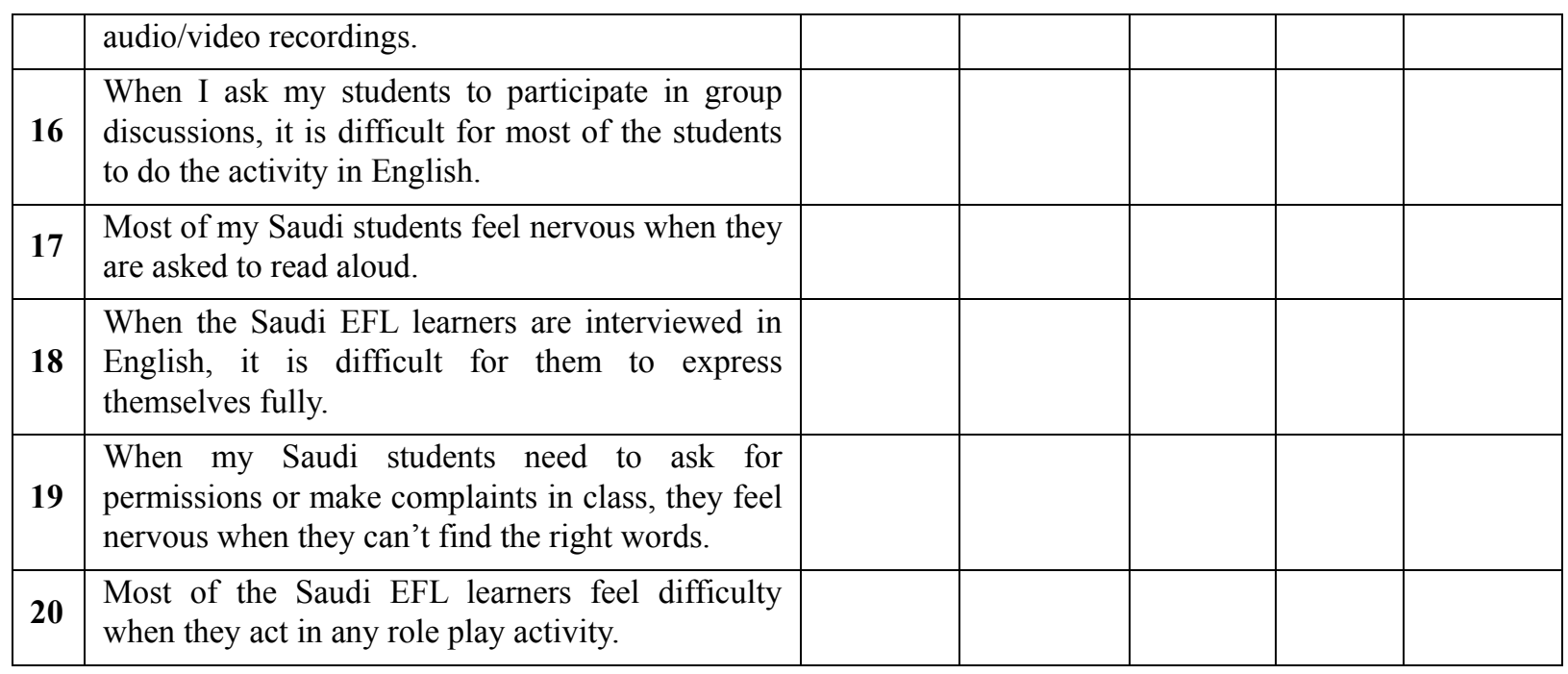

\section{Appendix: B}

\section{Interview questions for teachers}

Q.1: what do you think how anxiety affects your Saudi EFL learners' English learning proficiency?

Q.2: What are the factors, in your opinion, that cause anxiety among your Saudi EFL learners especially in speaking skill?

Q.3: And how would you describe some of the major signs of anxiety among anxious learners?

Q.4: What type of activities, skills and classroom situations do you think aggravate anxiety among the Saudi EFL learners?

Q.5: What suggestions would you like to give to handle the learners' anxiety in English language learning context?

\section{Copyrights}

Copyright for this article is retained by the author(s), with first publication rights granted to the journal.

This is an open-access article distributed under the terms and conditions of the Creative Commons Attribution license (http://creativecommons.org/licenses/by/4.0/). 